typical ancient objects as the famous iron pillar at Delhi, his most exhaustive investigation in this field being that of the alloys of iron prepared by Faraday and preserved at the Royal Institution. This was published in book form in 1931 .

Sir Robert Hadfield received many honours. He was knighted in 1908 and received a baronetey in 1917. He became a fellow of the Royal Society in 1909 , and was an honorary member of a great number of technical societies, many of which conferred on him their highest honours. He was president of the Iron and Steel Institute in 1905-7, and of the Faraday Society from 1913 until 1920, and those societies with which he was connected have reason to remember the keen attention which he gave to his duties and his boundless hospitality. Few men have worked so hard and with such system throughout a long life. $\mathrm{He}$ was an enlightened employer and a good citizen of Sheffield, where he occupied the position of Master Cutler in 1899-1900, being the second of his family to hold that office. $\mathrm{He}$ was a generous benefactor to the University of Sheffield and to other institutions, and gave much kindly encouragement to younger research workers. Shortly after the War of 1914-18 he put forward a scheme for an Empire Development Board, to which he gave much thought and energy. In 1894 he married Frances Bett, daughter of Colonel Samuel M. Wickersham, of Philadelphia. Lady Hadfield, who was created C.B.E. in 1918, worked from 1914 onwards in a hospital which she and her husband founded at Wimereux, and this work was continued during the present War as the Hadfield. Spears Ambulance.

C. H. Desch

\section{Dr. William Bowie}

Wrlliam Bowie, who died on August 28, aged sixty-eight, was best known in Great Britain perhaps as one of the most significant personalities of the International Union of Geodesy and Geophysics. For fourteen years he was the president of the Association of Geodesy, for three he was president of the Union itself, and at the last General Assembly (Washington, 1939) he undertook the duties of the general secretary, who had been recalled to England on the outbreak of war. His influence upon the Union was not confined to his mastery of geodesy or to his eminent work in isostasy, widely known and appreciated as these are. It rested just as much upon an enthusiasm and a strength of purpose which compelled co-operation and stifled the minor jealousies which are apt to clog the wheels of international work. It was a difficult matter to succeed the late $\mathrm{Ch}$. Lallemand who led the Union so brilliantly for fourteen years, but Dr. Bowie did, in fact, add to, rather than diminish, the significance of that post, because his geophysical interests were unusually wide and he could envisage no future in which geodesy did not work hand in glove with geophysics.

The United States Coast and Geodetic Survey has earned the gratitude of all surveyors. It has given us the 'figure of the earth' now used in all international work. It has followed and greatly enlarged upon, the fine record of the Survey of India in develop- ing isostasy. It has shown how geodesy may be subjected to mass production without losing precision. Even its observing towers and lamps came as something refreshing, efficient, simple, and practical. Dr. Bowie was the colleague of, and successor to, John F. Hayford in all these matters, and in our minds is also successor to Alexander Ross Clarke and Everest.

Dr. Bowie entered the U.S. Coast and Geodetic Survey in 1895 and served for forty-two years, of which twenty-eight were as chief of the Division of Geodesy. During the War of 1914-18 he served in the Engineers as a major in the mapping division, and this association with army and with mapping matters lasted until his death. He served on the federal "Board of Surveys and Maps" from 1920 onwards. Probably no one of his generation has more practically and strenuously studied and forwarded a mapping suited to the administrative, economic and industrial development of his country.

In 1919 the American Geophysical Union was founded. Dr. Bowie was its general secretary and, later, president. In his hands it grew in membership from fifty to thirteen hundred, and spread its influence over every territory of the United States. His services to that Union are commemorated by the William Bowie Medal, of which the first award fell, appropriately, to himself.

It would serve small purpose to list the twelve societies over which Bowie had presided or the even longer list of honours and awards which his own country had given to him. He had been honoured also by Belgium, Holland, and Yugoslavia. Edinburgh admitted him, in 1936, to the degree of doctor of laws. More even can be said of him as a strong, able, single-minded man devoted to the advancement of science, and, withal, a singularly likable friend. H. St. J. J. Winterbotham.

\section{Rev. Dr. W. G. Ivens}

WE regret to record the death of the Rev. Dr. Walter George Ivens, well known as an authority on the languages and ethnology of Melanesia.

After graduating at the University of New Zealand, Ivens joined the Melanesian Mission and laboured as a priest in Melanesia for a period of forty years. During this time he became widely known among scholars for his wide and profound knowledge of the numerous languages of Melanesia, as well as for his intimate acquaintance with their manners, customs, religious beliefs and observances. His "Melanesians of the South-East Solomon Islands" (1927), excellent in many respects, was followed three years later by the far more weighty "The Island Builders of the Pacific" (1930), in which, though it deals with a specialized form of culture, a certain breadth of philosophic outlook provokes reflection.

Dr. Ivens held the degree of Doctor of Letters of the Universities of New Zealand and Melbourne. During 1924-28 he was a research fellow of the University of Melbourne and during 1928-35 travelling secretary of the Melanesian Mission. He was a lecturer at the School of Oriental Studies in the University of London in 1936. 